\title{
Is an HIV vaccine achievable? - Pros
}

\author{
Marc Girard \\ From International Symposium HIV and Emerging Infectious Diseases 2014 \\ Marseille, France. 21-23 May 2014
}

The development of an HIV/ AIDS vaccine has been a long and difficult endeavor, which so far was met with a great many failures. New, recent advances may however change the deal. The RV144 clinical trial in Thailand showed that a canarypox-gp120 prime-boost vaccination regimen had a modest $31 \%$ efficacy at 42 months after vaccination, but protection was as high as $60 \%$ at 6 months after vaccination. A series of new trials is expected to take place in the near future to try to improve these numbers using a more potent vector than canarypox, gp140 rather than gp120, a water-in-oil adjuvant rather than aluminium salts, and increasing the number of booster immunizations. Protection in the RV144 trial correlated with the induction of antibodies $(\mathrm{Ab})$ to the $\mathrm{V} 2$ region of gp120, not with neutralizing Abs. A major difficulty met in the development of an efficacious HIV vaccine has indeed been to design proper immunogens able to elicit broadly neutralizing Abs (bnAbs) that can neutralize a wide range of circulating virus strains. BnAbs are highly protective, as demonstrated by passive immunization experiments and by vectored immunoprophylaxis experiments using AAV as a vector in animal models such as macaques or humanized mice. Their efficacy in humans should be tested soon in upcoming clinical trials. On another hand, the report that monkeys immunized with a simian CMV-SIV vaccine can clear SIV infection following viral challenge has emphasized the importance of self-renewing, long-lasting memory $\mathrm{T}_{\mathrm{EM}}$ cells that can differentiate into specific effector $\mathrm{T}$ cells and control provirus activation, eventually resulting in the clearance of infection. A HIV vaccine that could elicit both a bnAb response and the formation of specific $\mathrm{T}_{\mathrm{EM}}$ cells would obviously be an ideal vaccine. It might even offer hopes for a cure of HIV infection when used therapeutically in HIV-infected persons. The development of such a vaccine is still long and difficult but may not to be an unrealistic goal.

\footnotetext{
French National Academy of Medicine and Denis Diderot University, Paris,
} 75006, France

(c) 2014 Girard; licensee BioMed Central Ltd. This is an Open Access article distributed under the terms of the Creative Commons Attribution License (http://creativecommons.org/licenses/by/4.0), which permits unrestricted use, distribution, and reproduction in any medium, provided the original work is properly cited. The Creative Commons Public Domain Dedication waiver (http:// creativecommons.org/publicdomain/zero/1.0/) applies to the data made available in this article, unless otherwise stated. and take full advantage of:

- Convenient online submission

- No space constraints or color figure charges

- Immediate publication on acceptance

- Inclusion in PubMed, CAS, Scopus and Google Scholar

- Research which is freely available for redistribution Submit your manuscript at
www.biomedcentral.com/submit C BioMed Central
- Thorough peer review 